\title{
Securing the Ground Through Securitized 'Foreign' Policy: The Cyprus Case
}

\author{
ALPER KALIBER* \\ Bilkent University, Ankara, Turkey
}

\begin{abstract}
Particularly since the beginning of the new millennium, the Cyprus issue that had hitherto been successfully securitized and bureaucratized has turned out to be the main 'discursive battlefield' of the polarization among ruling elites in Turkey. Framed within a historical perspective, the present article re-examines Turkey's security discourse on Cyprus with particular reference to its implications for the (re)configuration of political balances and power relations between the conservative state elite - namely, the civilian and military bureaucracy - and the reformist political elite in Turkey. It concludes that the security language devised by the Turkish 'foreign' policy and security establishment has been operational in both inscribing the legitimate boundaries of the political sphere and crippling the manoeuvring ability of governments vis-à-vis the strong bureaucratic establishment in Turkey. The article also aims at encouraging the reader to critically reflect on power politics of 'foreign' policymaking in Turkey and its implications for domestic politics.
\end{abstract}

Keywords Cyprus $\cdot$ securitization $\cdot$ bureaucratization $\cdot$ foreign policymaking $\cdot$ Turkish military

$\mathrm{F}$ OR MANY IN TURKEY, the landing of Turkish troops on the small Mediterranean island of Cyprus in July and August 1974 amounts to the last act of the play staged on that island. Nevertheless, in contrast to such an ahistorical discourse, the implications of the Cyprus issue in contemporary Turkish domestic politics and 'foreign' policy are far more complicated than they used to be in previous decades. Of particular interest is its ever-increasing decisiveness and embeddedness within internal power relations in contemporary Turkish politics. From the end of 2002 onward, this embeddedness has reached such an extent that the Cyprus issue has turned out to be the main 'discursive battlefield' of the polarization among the conservative/statist and reformist ruling elites. 
Two imperative events can be cited as the reasons situating Cyprus at the centre of political debate in Turkey: The first is the November 2002 general elections in Turkey, which resulted in the overwhelming victory of the Justice and Development Party (AKP), defending a more reformist and integrationist attitude towards the European Union vis-à-vis the parties adopting a more nationalist, statist and Euro-sceptic line. The second is the establishment of an explicit linkage between the fate of Turkey's EU perspective and finding a solution to the Cyprus problem. However, instead of focusing on these, this study aims at addressing the official security discourse on Cyprus with particular reference to its implications for the (re)configuration of political balances and power relations between the state elite, namely the civilian and military bureaucracy, and the reformist political elite in Turkey.

Inspired by the post-structuralist account of 'foreign' policy as a 'boundary producing and disciplinary practice' (Campbell, 1998: 62) and the securitization approach of the Copenhagen School (Buzan, Wæver \& de Wilde, 1998), the main concern of this article is to introduce a power perspective into the analyses of the Cyprus question. As a matter of fact, getting a better insight into Turkey's security discourse on Cyprus necessitates reflecting on the actors and the relations between them that are influential in the formulation and transmission of that discourse. The article departs from the assumption that the main reason for the centrality of the Cyprus issue within domestic power relations in Turkey stems from its heavy - 'excessive', in Buzan's (1997: 21) terms - securitization by the 'foreign' policy and security establishment. Here, the term 'securitization' refers not primarily to militarization but rather to depoliticization within a technocratic and authoritarian discursive economy (see Wæver, 1998a: 46-86; Buzan, Wæver \& de Wilde, 1998; Wæver, 1998b: 69-118). Premised on this conceptualization, the present contribution outlines the crucial implications of Turkey's security discourse on Cyprus for internal power structures as follows: First, the casting of the Cyprus issue as one of national security has severely constrained the power and capacity of the political elite to intervene in the substance of existing policies. It has forced the government as the political authority to pursue predetermined policies by remaining loyal to the 'red lines' drawn up by the 'foreign' policy and security establishment. Second, the consistent efforts of the bureaucratic elite to hold the Cyprus question within the sphere of 'the existential' and 'the imminent' thwarted the occurrence of widespread social debate within an autonomous public sphere, and thus led to the depoliticization and fixation of the issue as an area of bureaucratic specialty and competence. Third, the effective insulation of 'foreign' policy issues in general, and the Cyprus case in particular, from public debate and the political domain has reinforced the power and hegemonic status of the bureaucratic apparatus, who 'consider them- 
selves as the ideological guardian of the "state"' (Yeldan \& Cizre, 2002: 17). Against this background, problematizing the official state line on Cyprus is also of great merit, for it permits an unravelling of the intimate relationality between securitization and bureaucratization - which is not adequately developed by the Copenhagen School. However, decoding this relationship is such an exhaustive task that it will require another article dedicated solely to that aim. The current work, often implicitly indicating some basic features of the relationship, can only stand for a bold and provocative step in further research into the topic. Suffice it to state at this point that the securitization of crucial 'foreign' policy issues - in this case, the Cyprus question imposes a definite conception of a political order in Turkey, an order in which the pro-status quo bureaucratic establishment can sustain its privileged position particularly vis-à-vis the reform-seeking wing of the political elite. ${ }^{1}$ On the other hand, moving the issues out of party politics by presuming that they are entangled within an area of bureaucratic competence both imperils questioning the state's securitized practices and serves to marginalize alternative discourses, which may eventually lead to the securitization of issues. Hence, securitization and bureaucratization may be considered as processes simultaneously triggering one another and ultimately leading to depoliticization, the antidote to which is desecuritizing the issues at hand.

To comprehend better the conventional Turkish rhetoric on Cyprus, I will first revisit the Copenhagen School by highlighting its analyses on securitization as an 'intersubjective' and 'conscious' political act. The objective of the following section is to discuss and demonstrate the main themes of the official security language on the Cyprus question. Official declarations and statements extracted from different historical epochs of the dispute will be examined to shed light on this securitizing practice. In the subsequent part, by drawing on Metin Heper's distinction between the state elite and the political elite in Turkey, the article addresses the role and impact of 'foreign' policy on domestic power/domination relations as a securitized and politically sacrosanct discursive space. In the concluding section, I will briefly touch upon some recent signs pointing to the erosion of the conventional approach to 'foreign' policy, which embraces the real potential of strengthening the hand of the reformist political elite and civil society.

${ }^{1}$ I should immediately state at this point that neither the bureaucratic nor the political elites can be presumed to be monolithic, homogeneous groups, for it is possible to speak of seminal cleavages among the public bureaucracy and the political elites, both comprising proponents of a more statist and nationalistic paradigm of politics or of political liberalism. Nevertheless, this does not prevent one from specifying the strong proclivities and dominant patterns of behaviour observable in the bureaucratic and political elites. 


\section{Securitization as an Intersubjective and Explicit Political Act}

Turkey has a multitude of soft and hard security concerns. Owing to historic, cultural, economic and strategic linkages, and the location of Turkey at the crossroads of Europe and Asia, as well as the Mediterranean and Black Sea Basins, these concerns are increasingly interconnected with security in the Balkans, the Caucasus, the Caspian region, the Persian Gulf and the Middle East. The most pressing concern for Turkey, however, is the bundle of disagreements with Greece. The Cyprus question is the knot that binds the bundle. (Olgun, 1999: 231-232)

The constant articulation of danger through foreign policy is not a threat to a state's identity or existence: it is its condition of possibility. (Campbell, 1998: 12-13)

From the 1990s on, the field of critical security studies has led to a theoretical revival within the discipline of International Relations as the primary forum in which broadly social constructivist approaches have challenged traditional - largely Realist and neorealist - theories on their "home turf"' (Williams, 2003: 511). Of these new critical positions, the securitization approach of the Copenhagen School has triggered the most vibrant debates. Despite some of its limitations, ${ }^{2}$ the Copenhagen School has managed to successfully introduce a power perspective to security studies, a power perspective through which the securitizing acts of domestic actors can be reappraised within the context of internal power/domination relations. As Johan Eriksson (1999: 315) has correctly argued, in the Copenhagen School securitization 'is seen as being about the power politics of a concept'.

Traditional realist paradigms presume the established definition of national security as an objective reality without attributing to it any normative and political implications as to domestic politics. In sharp contrast, for the Copenhagen School and other critical approaches to security inspired by the post-structuralist account of 'foreign' policy, there cannot exist objective threats (Campbell, 1998: 1-12), but 'only attempts to saddle issues with "security" implications. Thus, anyone who classifies an issue as a "security problem" makes a political . . decision' (Eriksson, 1999: 315). For Wæver, every attempt to securitize an issue is an explicit, political choice and an act with seminal consequences 'for which actors can be held responsible' (Buzan, Wæver \& de Wilde, 1998: 212). Securitization as a conscious political choice of the ruling elite "marks a decision, a "breaking free of rules" and the suspension of normal politics' (Williams, 2003: 518). It follows from the

${ }^{2}$ For criticisms of the Copenhagen School's securitization theory, see Bigo (2002); Aradau (2001); McSweeney (1996: 81-93); Eriksson (1999: 311-333); Williams (2003: 511-531); for a criticism of Buzan's (1991) state-centrism, see Bilgin (2002: 100-118). 
above analysis that security is a self-referential practice precisely because 'it is in this practice that the issue becomes a security issue' (Buzan, Wæver \& de Wilde, 1998: 24). In this sense, securitization can be treated as a 'disciplinary practice' and/or mechanism whereby issues are born into the field of the existential, the vital and the imminent.

This is where the particularly paradoxical nature of securitization can be revealed with the help of the Copenhagen School. Even though the basic motivation behind the act of securitization is to remove issues from the sphere of normal politics and to isolate them from public debate, the act itself is essentially a political intervention vulnerable to the claims of subjectivity and illegitimacy. This paradox and vulnerability, inherent in the nature of securitization, can be clarified by means of highlighting its three characteristics: First, securitization necessitates the use and perpetual repetition of a specific 'rhetoric of existential threat', through which issues are dramatized as issues of 'supreme priority' (Buzan, Wæver \& de Wilde, 1998: 24, 26) by the securitizing actor, which is all too often the government and/or bureaucratic establishments. Through the articulation of danger and existential threat to sovereignty, the securitizer demands justification from the audience (read society) for its initiatives, which are not otherwise legitimate. By declaring a specific threat to be a challenge to sovereignty, the securitizer also implies that all necessary means will be used to block that challenge (Wæver, 1998a: 56).

At this point, by making a new theoretical move, Ole Wæver and his colleagues reveal the second characteristic of securitization, which is intersubjectivity, rendering it a teleologically political process. Despite the fact that securitization is realized through subjective threat perceptions and calculations articulated by the securitizer, the word 'subjective' falls short of defining the process of securitization on the grounds that 'whether an issue is a security issue is not something individuals [read securitizer] decide alone' (Buzan, Wæver \& de Wilde, 1998: 31). The success of any attempt to securitize an issue is contingent upon the existence of an audience that accepts and tolerates acts by the securitizer that are not otherwise legitimate (Wæver, 2000: 251). Nevertheless, Buzan and Wæver do not unequivocally explain whether an explicit endorsement by an audience is necessary for the presumption that the conditions for such an acceptation have fully occurred. Even if they concede that the securitizing move is realized through either coercion or consent and is achieved through negotiations between the securitizer [read ruling elite] and the audience/society, they are not clear regarding the nature of the negotiation processes through which such approval for securitization is acquired. For instance, they do not discuss the role attributed to imposition, political manipulation through the media and other instruments, ${ }^{3}$ and the legal sanctions and restrictions applied by the

\footnotetext{
${ }^{3}$ For the importance of televisual communication within the process of securitization, see Williams (2003).
} 
securitizing agent to obtain such an acceptance. As in the case of Cyprus, issues may successfully be securitized through various legal and political mechanisms, ensuring the silence of the obedient. Therefore, approval is not necessarily preceded by a process of free discussion but, in some cases, can be identified with the absence of an explicit opposition to the securitizing move.

Third, the identity of the securitizer situates the securitization process undoubtedly in the centre of the political. To Wæver (1998a: 57), 'security is articulated only from a specific place, in an institutional voice, by elites'. As such, securitization as a speech act, a discursive and performative process, is utilized as a technique of governance, since by 'naming a certain development a security problem, the "state" can claim a special right, one that will, in the final instance, always be defined by the state and its elites' (Wæver, 1998a: 54). This paves the way for the instrumentalization of security by 'power holders' for their 'specific, self-serving purposes'. As one of several required but not sufficient 'felicity conditions', Wæver maintains that the speaker of security should have a 'social capital' and 'has to be in a position of authority' (Wæver, 2000: 252-253). What should be added to this analysis is the fact that security may also be utilized as a reproducer of this social capital. To illustrate, specifically the military wing of the Turkish state elite has customarily utilized its credibility in the eyes of the domestic society in declaring what the internal and external threats to the nation and state are. The provocative security lexicon it has used has also been functional in conveying the message to the society that 'notwithstanding unreliable, selfserving and even corrupt politicians, we are on duty, ready and alert'.

Considering the above, one may come to the conclusion that securitization as an intersubjective and explicit political act cannot be thought to be outside domestic power/domination relations within a given polity. For instance, in Turkey, where the domestic order was eclipsed by politics of security during the 1980s and the 1990s, the authoritarian nature of state-society relations during this period cannot fully be captured without examining the securitizing practices of the ruling elite. In this sense, my subsequent tasks will be, first, to discuss and exemplify the main tracks of Turkey's official security lexicon on Cyprus, and, second, to focus on its implications within domestic politics.

\section{The Securitizing Official Discourse on the Cyprus Question and the Centrality of Geopolitics}

The 'foreign' policy and security establishment in Turkey has always placed special emphasis on the geostrategically vital status of Cyprus for the 
country's defence and security. Mainly owing to the centrality of geopolitics, "the "strategic element" has continued to be of the utmost importance in Turkish calculations' (Kazan, 2002: 58) since the existence of the Cyprus problem was formally recognized in Turkey in the middle of the 1950s. In the rhetoric of the 'foreign' policy and security establishment, the Cyprus issue, involving 'Turkey's vital national and strategic interests' (Turkish Ministry of Foreign Affairs, quoted in Kazan, 2002: 57) has Janus-faced implications in Turkey's strategic calculations and threat perceptions: the geographical proximity of the island to the Anatolian heartland is made use of to represent the issue in domestic politics either as a source of imminent, fatal and persistent threat to the Turkish nation and state or as an indispensable element and integral part of Turkey's national defence and security.

\section{Cyprus as a Source of Existential Threat and the Fear of Encirclement}

While depicting how Cyprus constitutes an urgent and persistent threat to Turkey's rights and existence, the discourse of encirclement has been recurrently referred to within the official and mainstream argumentation. 'Stuck in its southern underbelly, Cyprus is a major source of concern for Turkey', and 'it is the final, southern element in the containment of Turkey' (Olgun, 1999: 232). The island, which has a 'strategic position to control the important Turkish harbours of Iskenderun and Mersin', can easily be utilized by a hostile power as a 'springboard for the conquest of Anatolia from the South' (see Kazan, 2002: 58). This argument is based on the presumption that 'an unfriendly power lodged in Cyprus could easily strike the nation's Anatolian heartland' (İsmail, 1989: 137). From the military and strategic perspective, any state dominant on the island would have a say in 'the fate of Turkey', since 'if this dominant power is also the same dominant power on the islands to the west [of Turkey], Turkey would be de facto encircled' (former Turkish prime minister F. Rüştü Zorlu, quoted in Kazan, 2002: 58). Encapsulated in all these excerpts is the idea that the real threat is Greece itself. This is the reason why the discourse and fear of encirclement locates the Cyprus issue directly into the field of 'vitality' and 'emergency'.

Turkey's Aegean coast is blockaded because of the possession of the Dodeconese Islands by Greece. As a matter of fact Turkey's only free access to the sea is its southern shores. About 40 miles away from these shores is the island of Cyprus. Possession of Cyprus by Greece through Enosis, would have meant the encirclement of the southern shores of Turkey as well. Therefore Turkey had to destroy the de facto situation created by the coup of 15 July with the military intervention of 20 July. (Issmail, 1989: 171)

Throughout the 1990s, during which the parameters of security and being secure dramatically altered at the global scale, ascendancy of the discourse of encirclement remained intact in Turkey's official outlook on Cyprus. Cyprus 
continued to be imagined as 'the cornerstone of Greece's policy of enveloping Turkey with a strategic belt of hostile states' (Olgun, 1999: 231-232). For instance, the signing of military and technical cooperation agreements between Armenia and the Greek-controlled sector of Cyprus has been interpreted by both Turkish and Turkish-Cypriot 'foreign' policy and security establishments as 'an attempt at the encirclement of Turkey and the Turkish Republic of Northern Cyprus by the hostile forces' (Ministry of Foreign Affairs and Defence of the TRNC, 2002). In the same vein, remarks by the chief of the Turkish General Staff Hilmi Özkök in January 2003 regarding recent developments in Cyprus in the light of UN Secretary-General Kofi Annan's peace plan are stunningly revealing. According to the leader of the Turkish military, in the event of acceptance of Annan's proposals 'the entrapment of Turkey in Anatolia' (Güven, 2003; Taşgetiren, 2003; Kathimerini, 2003) would have been completed. This rather fervent rhetoric qualifying Annan's plan as a threat to Turkey's security stands out as a perfect illustration of the securitization of an issue that is political in nature. ${ }^{4}$

\section{Cyprus as an Indispensable Element of Turkey's National Security}

Even though the discourse on the 'undeniable' and 'fragile' rights of the Turkish-Cypriot minority occasionally gained ascendancy, especially in the 1960s and 1970s, the language encoding the Cyprus question primarily as an issue of national security has proved its durability and dominance until recent years. The second component of this 'security speak' hinges upon the notion that Cyprus is an inexorable and integral part of Turkey's national defence and security. The following statement by Turan Güneş, Turkey's foreign minister in the left-leaning Ecevit cabinet during Turkey's military intervention of July-August 1974 in Cyprus, reveals how the Turkish state elite understands and expresses the nature of the Cyprus question:

Cyprus is as precious as the right arm of a country which cares for her defence or her expansionistic aims if she harbours any. If we don't keep this strategic importance of Cyprus we cannot understand the peace operation of 20 July [1974] or rather it is impossible to understand the entire Cyprus crisis. . . . Many states, to a certain extent because it suits their interest, want to see the Cyprus problem merely as our desire to protect the Turkish community on the island. Whereas the actual problem is the security of 45 million Turks in the motherland together with the

${ }^{4}$ This discourse of threat adopted by the Turkish military with regard to the Annan Plan seemed to have softened by January 2004. In a statement issued by the National Security Council after its meeting on 23 January 2004, it was declared that 'Turkey continues to support the U.N. secretary-general's goodwill mission and has renewed its political determination to rapidly reach a solution that takes the Annan plan as a reference' (Turkish Daily News, 2004b). However, it is difficult to say that this new position is shared and internalized by all echelons of the Turkish bureaucracy or by Rauf Denktash, the former president of the TRNC. 
Turks in the island and the maintenance of the balance of the Middle East. (Hürriyet, 1980)

The notion that Cyprus is geographically a part and natural extension of Anatolian heartland, and thus an integral part of its defence and security, has been articulated by many prominent Turkish bureaucratic and political figures throughout the long history of the dispute. In the words of former Turkish prime minister Adnan Menderes, 'Cyprus is but the continuation of Anatolia and constitutes one of the pivotal elements as regards its security' (quoted in Armaoğlu, 1963: 133). The approach equating the security of the Turkish state with that of the TRNC is illustrated in remarks by another former Turkish prime minister, Bülent Ecevit: 'we now believe that not only is Turkey guarantor of the security of the TRNC, but at the same time we consider the existence of the TRNC to be a necessity for the security of Turkey' (Kazan, 2002: 61). In a joint declaration between Turkey and the TRNC, 'both sides have emphasized the increasing importance of the TRNC for the security of Turkey, while Turkey continues to provide effective guarantee for the TRNC' (Turkish Ministry of Foreign Affairs, 1997). The widely used metaphor of 'motherland-babyland' in Turkey's official and popular discourse also implies the inseparability and intertwinedness of the security of the two. This metaphor serves to emphasize both indissoluble and sacred linkages between Motherland Turkey and Babyland Cyprus and the unity of their fate and destiny.

The quotations under the last two subheadings reveal that within Turkey's security language the Cyprus issue signifies two seemingly paradoxical connotations. On the one hand, it implies the existence of a vital and imminent threat to Turkey's national security. On the other, it is an integral part of national defence, the absence of which would create a substantial hole in the protection of Turkey's territorial integrity. Even though these modes of representation seem paradoxical at first glance, they are complementary in the sense that, in either case, the island refers to an 'unsinkable aircraft carrier' (Kazan, 2002: 58) bound to be used by a hostile power to strike the Anatolian heartland, or that can be used by Turkey against that aggressive state. Thereby, within this technical-sounding securitizing language imbued with excessive geopoliticism, the island of Cyprus is simultaneously the cornerstone in the encirclement of Turkey and its only access to the Eastern Mediterranean from the south. This geopoliticism, to which I will return in the subsequent pages, sets out the intimate relationality between securitization and bureaucratization by highlighting the indispensability of the island as a geostrategic asset. 


\section{'Foreign' Policy as a Secured Area of Bureaucracy: A Brief Glance at Post-1980s Turkey}

Even though the Cyprus issue is generally approached by most Turkish IR scholars only within the context of the Turkish state's external relations, it has increasingly turned out to be an integral part of Turkey's internal power relations. To shed more light on this aspect, I will draw on Metin Heper's (1992) distinction between the state elite and the political elite in Turkey. To Heper, throughout the period of Turkish modernization, 'from the 19th century onward, the bureaucratic and/or military elites [read the state elite] acted in the belief that they themselves were solely responsible for maintaining order and modernizing their country' (Heper, 1992: 176). These state elites, perceiving themselves as the 'ultimate guardian' of the state, nurtured deep mistrust and suspicion of the political elites, particularly if the latter claimed to represent peripheral social groups disenchanted with the state's project of radical modernization. ${ }^{5}$ When political groups remained outside the centre and could not internalize the social and political norms and values established by the state elite, this polarity and the conflicts embedded in it grew exponentially.

In the Republican era (beginning in 1923), the Kemalist state elite foresaw that Turkish society would move en masse towards Westernization. This modernizing cadre envisioned 'an organized, well-articulated, linear process of modernization' (Kasaba, 1997: 16-17), the political, cultural and ethical limits of which were inscribed solely by the state itself. However, particularly from the middle of the 20th century onward, a new formation within the political elite has reinvigorated against the bureaucratic and political establishment. Unlike the latter, they foregrounded the priority of the national will vis-à-vis the exigencies of the raison d'etat. Since then, almost all fields of political, economic and cultural life in Turkey have become discursive and performative battlefields for the polarity between the Kemalist state elite and this fledgling political elite.

Throughout the more than 80 years' history of the Turkish Republic, 'foreign' policy has been the sphere where such polarization was kept at a minimum level, if it occurred at all. Insofar as the political leaders whose statist Weltanschauung and reflexes were as strong as those of the bureaucratic establishment remained in power, an unreserved compromise concerning how 'foreign' policy issues were to be governed lingered on. Even seemingly reformist politicians avoided publicly questioning the democratic legitimacy of the Republicanist tradition of 'foreign' policymaking, placing

\footnotetext{
${ }^{5}$ For an analysis of Ottoman-Turkish modernization within the context of the centre-periphery dichotomy,
} see Mardin (1973). 
'foreign' policy beyond normal politics and public debate. More strikingly, the military's decisive role and impact on 'foreign' affairs has been tolerated, and at times deemed necessary, both by governments and the public in Turkey (Uzgel, 2004: 313). The Kemalist state elite conceived 'foreign' policy and wanted others to conceive it as a vital sphere in pursuit of Turkey's national interests and security goals. During the Cold War years, most political leaders, either willingly or because they avoided assuming the responsibility for any deviancy from the politics of security, contributed to the reproduction of securitizing discourses in the field of 'foreign' affairs. In most cases, 'foreign' political acts of the Turkish state have been presented by the ruling elite as endeavours to ward off external threats directed against the state's unity and integrity. Thus, in the official rhetoric, as exemplified in the Cyprus case, 'foreign' policy referred to a battlefield to be entrusted only to those cognizant of its peculiar rules and techniques.

Within this conceptualization, it was deemed futile and non-functional to open up 'foreign' policy decisions and discourses of the state to the discussion of the 'ignorant masses', who were expected only to clamp around the national policies. Similarly, the role and significance of various governments often remained marginal regarding 'vital' 'foreign' policy issues. Governments had no alternative other than to pursue policies already formulated by the Turkish bureaucratic elite, especially if they were labelled 'state policies' and/or 'national causes' (Kaliber, 2003: 217-275). As aptly put by Philip Robins, the process of 'foreign' policymaking has not been managed in Turkey in the way it has been done in full-fledged democracies:

In Turkey, the guidelines of grand strategy, of high politics belong not to the government of the day as an expression of the popular will, but to the highest priests of Kemalism, as an expression of the ideals of Atatürk. These guardians of the sacred will consist first and foremost of the senior officer corps of the military, supplemented at a secondary level by parts of the bureaucracy, and the top diplomats in the case of the Foreign Ministry. (Robins, 2003: 69)

This governmental rationality, in which governments do not govern, can be certified by scrutinizing various statements made by Turkish political and bureaucratic figures on the Cyprus issue. For example:

If an aggressive move directed against us through our community turns into a dispute, we shall not hesitate for a moment to implement the predetermined elements of our policy on the subject. I am certainly not saying this in the sense of a threat. This is the basis of our established policy fixed for years as a Nation and State. Governments have changed, and may change but policy of Turkey on Cyprus does not change. (Haluk Bayülken, former Turkish minister of foreign affairs, quoted in Söylemez: 1973: 297)

According to this line of thought, echoed by another former Turkish minister of foreign affairs, F. R. Zorlu, 'Turkish people cannot think differently 
about the future of an island which is existentially important to the defence of its country' (quoted in Kazan, 2002: 58). The official state line epitomized in these words presumes an absolute unity and unproblematic identicalness between the state and society, and also imagines the latter as a unified and homogeneous totality.

This mindset, reflecting the consensus among the top political and bureaucratic figures until recent years, provokes questions about the effectiveness and capacity of governments insofar as 'foreign' policy is concerned.

The contours of Turkish foreign policy are drawn, under the rubric of 'state policies', by the 'armed' bureaucracy and its extensions in the Ministry of Foreign Affairs. If there exist established 'state policies', what is the relevance then of changing the ruling government? (Altan, 2002)

The nature of the political system, in which governments are forced not to transcend the 'red zones' of the 'foreign' policy and security establishment, did not just severely restrict the capacities of governments to govern. It also gave the statist/nationalist political and bureaucratic establishment a proper ground on which it could easily delegitimize opposition, since criticizing these fixed policies amounted to criticizing the regime and the state itself. More or less radical criticisms directed at the official state line tend to be evaluated as opposition to 'the state's indivisible identity with the country and the nation' (Bora, 2003: 438), especially if these are related to issues associated with national security. As a result, the 'foreign' policy choices and actions of a narrow state class have managed to remain exempt from public debate and questioning until very recently.

Our case of Cyprus also underpins the point that, mainly owing to the confinement of issues within a technical security language, 'the dominant mode of political imagination becomes technical know-how and technocrats become the substitute for politicians. This anti-political mind-set is particularly apparent with regard to the expansion of the autonomy of civil and military establishment' (Yeldan \& Cizre, 2002: 14-15). For instance, the indispensability of Cyprus for Turkey's national defence and security is often expressed through complex regional and global strategic calculations and threat perceptions (Davutoğlu, 2001: 175-180). Within this logic, the geostrategically salient position of the island as an objective and unchanging reality forces Turkey to pursue a definite policy of security that has to be based on technical know-how, expertise and long-term strategies. A news analysis that appeared on 5 March 2003 in the Turkish Daily News, reputed to have close ties to the Turkish Ministry of Foreign Affairs, made for interesting reading. According to the paper, 'some military analysts' maintained that

whatever the strategy the AK Party headquarters could produce, as was laid down clearly at the latest Feb. 28 National Security Council (MGK) meeting, Turkey must be ready for new possible tensions in the entire 
southern front from Cyprus to Iraq, and must act with the awareness that every stone in that front is linked with each other. 'We must know that the loss of one playing piece may bring about a total defeat,' a leading source commented, stressing that a 'retreat' from the Cyprus position could land Turkey in a position to 'retreat' in all fronts, including the EU. (Turkish Daily News, 2003)

As Bilgin (2005: 186-187) puts it, 'geographical determinism' - also observable in defining Turkey's own geographical location and the 'tough neighbourhood' in which it is located - 'has been used to legitimize the adoption of a particular concept of national security that does not allow for further democratization'. It is mainly owing to this objectivist geopoliticism that an inner link between securitization and bureaucratization is constituted and kept alive via a technical and depoliticized security lexicon. According to a widespread understanding within the Turkish military corps, in order for the national 'foreign' and security policy to be successful it should be exempt from the infertile discussions of daily political haggling and pressures from social groups and political parties that may seek their own subjective interests (Özcan, 2002: 21). Undoubtedly, the widespread dissemination of this technocratic security outlook throughout the 1990s recognized a considerable space for the military to institutionalize its autonomy both in domestic politics and 'foreign' policy. Throughout the period, Turkish politics witnessed the swift pervasiveness of the discourse and practices of the Turkish state elite bearing almost all 'domestic' and 'foreign' issues into the field of security and vitality.

When the late 1990s arrived, the military emerged 'more publicly than at any time ... as the most important institution, at least in charting the strategic dimension of "foreign" policy' (Robins, 2003: 92). This institutional autonomy enjoyed in 'foreign' affairs has been instrumentalized by the Turkish military in narrowing the boundaries of the domestic political space in favour of security.

As the sole actor defining internal and external threats, the military, while making use of its weight in domestic politics to have a say on foreign policy making, benefited from external threats to consolidate and further increase its role and impact on domestic politics. Assuming itself as the principal element of the Turkish state, the military has created itself an autonomous realm besides already feeble civil society. (Uzgel, 2004: 312)

This not only posed a major obstacle in the insertion of a wide range of political issues into the public sphere, but also set the proper ground for the National Security Council (NSC) to increase its power and authority in order to intervene across the entire spectrum of socio-political and cultural life in Turkey. In particular, immediately after the 1980 military coup, the NSC and its secretariat have been the most sophisticated instruments for the military top brass to consolidate their authority in shaping national 'foreign' and 
security policies (Özcan, 2002: 17). Even though, under Article 118 of the Constitution of the Republic of Turkey, the NSC is formally an advisory body to the government,

in practice it is virtually unheard of for cabinets and parliaments publicly to question its views, and it is a proud claim made by the NSC secretariat that there are no examples of recommendations in the realm of foreign policy that have remained unimplemented. (Robins, 2003: 76)

The secretariat, traditionally chaired (until October 2004) by a top military figure, not only undertakes to set the agenda of the NSC meetings but also coordinates 'the government's efforts to implement NSC decisions' and controls 'whether decisions proposed by the council are fully implemented on time' (Özcan, 2002: 18).

The other crucial source of the military's considerable stature in the field of 'foreign' affairs is the highly confidential National Security Policy document. 'Nicknamed the "red booklet", the document lists the threats to national security, sets out the priorities, lays out policy guidelines, and provides a detailed framework of foreign and security policies for governments and state institutions' (Özcan, 2002: 20). Updated when deemed necessary, this document defines not only what internal and external threats are but also their status (i.e. principal or secondary) within official threat calculations. As indicated by Özcan (2002: 20), 'no government can pursue a policy that contradicts the document, which was concluded without any parliamentary debate, classified as top secret, and retained by the NSC secretariat'. Briefings delivered by the military to high-ranking bureaucrats, prominent political figures, academic circles and the media, as well as polemical discussions with eminent political figures via the press, have been other clear manifestations of the military's direct involvement in 'foreign' affairs. Even if these sorts of interventions are becoming increasingly uncommon, the military is keeping a close track of such critical 'foreign' policy issues as 'Cyprus, Aegean, Northern Iraq, relations with Israel and NATO' (Uzgel, 2004: 314). The military is neither 'the only component of the security establishment' (Robins, 2003: 77) nor the only producer of securitizing 'foreign' policy discourses in Turkey. Nevertheless, understanding its institutional weight and autonomy in the process of 'foreign' policymaking provides valuable insights as to how this process itself is cast into the field of security and bureaucracy.

\section{Hope for the Future?}

If 'the historical foundations of Turkish state structure' have really been shaped 'between conflicting forces of political liberalization and security' 
(Aydinl1, 2002: 210), as one Turkish IR scholar argues, then Cyprus has always increased the manoeuvring ability of the latter at the expense of the former. In the 'pendulum swing' between political normalization and securitization, Cyprus has served as a trump card in the hands of the securitizers. Furthermore, 'lack of a meaningful and critical public debate that goes beyond scientific sounding technicalities' (Yeldan \& Cizre, 2002: 15) has hindered the outbreak of genuine alternative arguments and has ultimately eased the bureaucratization of the Cyprus issue. Hence, the conventional state rhetoric on the Cyprus question substantially contributed to the institutionalization of a regime fetishizing such concepts as security, stability and 'national sensitivities' in Turkey. This was a regime in which security began to substitute for politics and was 'conceived of as synonymous with public policy, thus granting the military a free entry into policy making' (Cizre, 2003: 219).

However, the 1990s were also the years during which 'pressures for further democratization continued to well up from within the Turkish society' (Özel, 2003: 85). While the desecuritization of political issues never took priority in the agenda of most ordinary Turks, the demands to further civilianize and liberalize the polity began to be articulated more loudly. Strikingly, the demands for political liberalization have primarily been articulated owing to the debates on issues traditionally thought to pertain to the sphere of 'foreign' policy. 'Foreign' policy, which was excessively securitized and successfully insulated from the public domain, became the area in recent years where the boundaries demarcating 'the political' from 'the societal' began to dissolve. Turkey's strengthening EU vocation in the wake of the Helsinki Summit of December 1999, where Turkey was granted the status of a candidate for full membership, and the successive adoption of major constitutional and legal amendments by the National Assembly since August 2001, have become the main thrust behind this process of transformation.

Although less and less frequently, the chief of the Turkish General Staff is still making assertive political assessments concerning a wide range of issues, from domestic politics and Turkey's bilateral relations with neighbouring countries to the Cyprus issue (Özkök, 2005). However, especially in the field of 'foreign' affairs, such 'security speak' has been substantially downplayed, given a status as simply one of numerous competing discourses in the public realm. Unlike its predecessors, the current government, for instance, has avoided using a securitized discourse on the Cyprus dispute. Notwithstanding the military viewpoint regarding the Annan Plan as a threat haunting the national interests of both Turkey and Northern Cyprus, the AKP government vigorously encouraged Cypriot Turks to endorse the UN's blueprint in the referendum on 24 April 2004. Moreover, the EU-led reforms to strengthen the NSC's civilian component and to 
restructure the setup and responsibilities of its secretariat facilitated, to a certain extent, a lessening of the securitizing tone in Turkish 'foreign' policy discourse.

In tandem with the resurgence of efforts to find a viable solution to the Cyprus problem within the framework of the Annan Plan, Turkey's conventional Cyprus policy has moved back into the public arena and has begun to be criticized more extensively than before. These debates are a relatively recent yet historically significant political experience for the Turkish society through which it can relocate itself within the system as a real political subject vis-à-vis the state. These developments, however, do not imply that Turkish society has necessarily acquired a more liberal and desecuritized understanding of 'foreign' policy and the Cyprus question than that of the state. Nevertheless, that Turkish 'foreign' policy matters have turned out to be part and parcel of public debate has created a chance for political mobilization - and hence democratization of state-society relations in Turkey - that cannot be ignored.

On 17 December 2004, the Council of the European Union, after intense bargaining and even a series of diplomatic bluffs, expressed its decision to open accession negotiations with Turkey by 3 October 2005 (Council of the European Union, 2004: 6). The Cyprus issue was the only ground for a possible diplomatic crisis between Turkey and the EU, avoided by lastminute efforts. To get membership talks started, Turkey has agreed to sign a protocol extending its 1963 Association Agreement to the ten new members of the EU, including the Republic of Cyprus, which it does not de facto recognize (Turkish Daily News, 2004a; Council of the European Union, 2004: 6). The bargaining process itself and the subsequent document demonstrate that the Cyprus issue will necessarily continue to be the most critical item on the Turkish-EU agenda. Even if it is difficult to foresee the political consequences of the increasing EU involvement, it will obviously place the Cyprus issue at the core of public debate in Turkey. These discussions should at least be deemed an opportunity for shifting the question from the sphere of security politics into the boundaries of normal politics. I am convinced that every attempt to desecuritize - in other words 'to move issues out from the threat-defense sequence into the ordinary public sphere' (Buzan, Wæver \& de Wilde, 1998: 29) - will substantially contribute both to finding a just and viable solution to the dispute and to the democratic transformation of the political regime in Turkey.

* Alper Kaliber received his BA and MA in International Relations from Bilkent University, Turkey. He also completed his D.Phil. in Political Science at Bilkent University, submitting a thesis entitled 'Rearticulation of Turkish Foreign Policy, Its Impacts on National/State Identity and State Society Relations in Turkey: The Cyprus Case'. Dr Kaliber served as a Visiting Research Fellow at Birmingham University between December 2003 and June 2004, conducting research on the impact of Turkish-EU 
relations on Turkey's domestic politics and civil society with Dr Thomas Diez, and currently teaches European security at Sabanci University, Turkey. He would like to thank the three anonymous referees of Security Dialogue for their helpful comments and Esra Kaliber for her able assistance.

\section{References}

Altan, Mehmet, 2002. Interviewed by Neşe Düzel, Radikal, 16 December.

Aradau, Claudia, 2001. 'Migration: The Spiral of (In)security', Rubikon International Forum of Electronic Publications; available at http://venus.ci.uw.edu.pl/ rubikon/forum/ claudia1.htm (accessed 12 September 2004).

Armaoğlu, Fahir, 1963. Kıbrıs Meselesi 1954-1959 [The Cyprus Question, 1954-59]. Ankara: Sevinç Matbaası.

Aydınl, Ersel, 2002. 'Between Security and Liberalization: Decoding Turkey's Struggle with the PKK', Security Dialogue 33(2): 209-225.

Bigo, Didier, 2002. 'Security and Immigration: Toward a Critique of the Governmentality of Unease', Alternatives (27): 63-92.

Bilgin, Pinar, 2002. 'Beyond Statism in Security Studies? Human Agency and Security in the Middle East', The Review of International Affairs 2(1): 100-118.

Bilgin, Pinar, 2005. 'Turkey's Changing Security Discourses: The Challenge of Globalisation', European Journal of Political Research 44: 175-201.

Bora, Tanil, 2003. 'National Discourses in Turkey', The South Atlantic Quarterly 102(2/3): 433-542.

Buzan, Barry, 1991. People, States and Fear: An Agenda for International Security Studies in the Post-Cold War Era, 2nd edn. London: Harvester Wheatsheaf.

Buzan, Barry, 1997. 'Rethinking Security after the Cold War', Cooperation and Conflict 32(1): 5-28.

Buzan, Barry; Ole Wæver \& Jaap de Wilde, 1998. Security: A New Framework For Analysis. Boulder, CO: Lynne Rienner.

Campbell, David, 1998. Writing Security: United States Foreign Policy and the Politics of Identity, rev. edn. Minneapolis, MN: University of Minnesota Press.

Cizre, Ümit, 2003. 'Demythologizing the National Security Concept: The Case of Turkey', Middle East Journal 57(2): 213-230.

Council of the European Union, 2004. 'Presidency Conclusions of the Brussels European Council', 16238/04, 16-17 December; available at http://ue.eu.int/cms3_fo/ showPage.asp?id=432\&lang $=$ en\&mode $=\mathrm{g}$ (accessed 21 December 2004).

Davutoğlu, Ahmet, 2001. Stratejik Derinlik: Turkiyénin Uluslararasi Konumu [Strategic Profoundness: Turkey's International Position]. Istanbul: Küre Yayınları.

Eriksson, Johan, 1999. 'Observers or Advocates? On the Political Role of Security Analysts', Cooperation and Conflict 34(3): 311-333.

Güven, Erdal, 2003. 'Kıbrıs'ta Yeni Politika Bekleyelim, Görelim' [The New Policy in Cyprus: Let's Wait and See], Radikal, 10 January.

Heper, Metin, 1992. 'The Strong State as a Problem for the Consolidation of Democracy: Turkey and Germany Compared', Comparative Political Studies 25(2): 169-194.

Hürriyet (Istanbul), 1980. 20 July; translated into English and quoted at http://www. hellas.org/cyprus/trexpand.htm (accessed 7 June 2005).

İsmail, Sabahattin, 1989. 20th July Peace Operation: Reasons, Development and Consequences. Istanbul: Kastaş.

Kaliber, Alper, 2003. 'Rearticulation of Turkish Foreign Policy, Its Impacts on National/ 
State Identity and State Society Relations in Turkey: The Cyprus Case', unpublished PhD dissertation, Ankara: Bilkent University.

Kasaba, Reşat, 1997. 'Kemalist Certainties and Modern Ambiguities', in Sibel Bozdoğan \& Reşat Kasaba, eds, Rethinking Modernity and National Identity in Turkey. Washington, DC: University of Washington Press (15-36).

Kathimerini (Athens), 2003. 'Turkish Cypriots Prepare Protest', English edition, 10 January.

Kazan, Iş1l, 2002. 'Cyprus and the Eastern Mediterranean, Seen from Turkey', in Thomas Diez, ed., The European Union and the Cyprus Conflict: Modern Conflict Postmodern Union. New York: Manchester University Press (54-69).

McSweeney, Bill, 1996. 'Identity and Security: Buzan and the Copenhagen School', Review of International Studies 22(1): 81-93.

Mardin, Şerif. 1973. 'Center Periphery Relations: A Key to Turkish Politics?', Daedalus 102 (Winter): 169-190.

Ministry of Foreign Affairs and Defence of the TRNC, 2002. Statement by the Ministry of Foreign Affairs and Defence of the Turkish Republic of Northern Cyprus, 1 March; available at www.trncinfo.com/ENGLISH/PRESSRELEASE/010302.htm (accessed 5 March 2003).

Olgun, Mustafa Ergün, 1999. 'Turkey's Tough Neighbourhood: Security Dimension of the Cyprus Conflict', in Clement H. Dodd, ed., Cyprus: The Need for New Perspectives. Cambridgeshire: Eothen (231-260).

Özcan, Gencer, 2002. 'The Military and the Making of Foreign Policy in Turkey', in Barry Rubin \& Kemal Kirişçi, eds, Turkey in World Politics: An Emerging Multiregional Power. Istanbul: Bogaziçi University Press (13-30).

Özel, Soli, 2003. 'After the Tsunami', Journal of Democracy 14(2): 80-94.

Özkök, Hilmi, 2005. Speech by the Commander of the Turkish Armed Forces General Hilmi Özkök at the Turkish War Colleges, 20 April; available at http://www.tsk. mil.tr/eng/konusma/harpakademisikonusma20Nisan.htm (accessed 30 April 2005).

Robins, Philip, 2003. Suits and Uniforms: Turkish Foreign Policy Since the Cold War. London: Hurst.

Söylemez, Yüksel, ed., 1973. Foreign Policy of Turkey at the United Nations Between the Years 1966-1972, vol. 1. Ankara: Ministry of Foreign Affairs.

Taşgetiren, Ahmet, 2003. 'Davutoğlu'nu Okumak' [Reading Davutoğlu], Yeni Şafak, 28 January.

Torumtay, Necip, 1997. Değisşen Stratejilerin Odağında Türkiye [Turkey on the Focus of Changing Strategies], 2nd edn. Istanbul: Milliyet Yayınları.

Turkish Daily News (Ankara), 2003. 'Denktaş Arrives for Crucial Cyprus Summit', 5 March.

Turkish Daily News (Ankara), 2004a. 'Rush for October 3', 24 December.

Turkish Daily News (Ankara), 2004b. 'New Cyprus Push Under Way', 26 January.

Turkish Ministry of Foreign Affairs, 1997. Joint Statement by the Republic of Turkey and the Turkish Republic Of Northern Cyprus, 20 July; available at http://www. mfa.gov.tr/grupa/ad/add/doc4.htm (accessed on 5 March 2003).

Uzgel, Ilhan, 2004. 'Ordu Diş Politikanın Neresinde?' [Where Does the Military Stand in Foreign Policymaking?], in Ahmet Insel \& Ali Bayramoğlu, eds, Bir Zümre Bir Parti: Türkiye'de Ordu [The Military in Turkey: A Class or a Party?]. Istanbul: Iletişim (311-334).

Wæver, Ole, 1998a. 'Securitization and Desecuritization', in Ronnie D. Lipschutz, ed., On Security. New York: Columbia University Press (46-86).

Wæver, Ole, 1998b. 'Insecurity, Security and Asecurity in the West European Non-War 
Community', in Emmanuel Adler \& Michael Barnett, eds, Security Communities. Cambridge: Cambridge University Press (69-118).

Wæver, Ole, 2000. 'The EU as a Security Actor: Reflections from a Pessimistic Constructivist on Post-Sovereign Security Orders', in Michael Kelstrup \& Michael C. Williams, eds, International Relations Theory and the Politics of European Integration. London: Routledge (250-294).

Williams, Michael C., 2003. 'Words, Images, Enemies: Securitization and International Politics', International Studies Quarterly 47: 511-531.

Yeldan, Erinç \& Ümit Cizre, 2002. 'Turkey: Economy, Politics and Society in the PostCrisis Era'; available at http://www.networkideas.org/feathm/jul2002/Turkey.pdf (accessed 5 June 2005). 